Article

\title{
Love as Descent: Comparing the Models of Proclus and Dionysius through Eriugena
}

\author{
Dimitrios A. Vasilakis
}

Citation: Vasilakis, Dimitrios A. 2021.

Love as Descent: Comparing the

Models of Proclus and Dionysius through Eriugena. Religions 12: 726. https://doi.org/10.3390/rel12090726

Academic Editors: Eva Anagnostou,

Georgios Steiris and

Georgios Arabatzis

Received: 20 August 2021

Accepted: 31 August 2021

Published: 5 September 2021

Publisher's Note: MDPI stays neutral with regard to jurisdictional claims in published maps and institutional affiliations.

Department of Philosophy, National and Kapodistrian University of Athens, 15784 Athen, Greece dimvasilakis@philosophy.uoa.gr

\begin{abstract}
This paper explores the models of the providential-erotic descent in Neoplatonism and Christianity and the ethical consequences that these two models entail. Neoplatonic representative is an excerpt from Proclus' Commentary on the First Alcibiades, where a parallel with ancient Greek mythology is drawn: Socrates' providential love for Alcibiades is compared to Hercules' descent to Hades in order to save Theseus. This image recalls not only the return of the illumined philosopher back to the Cave (from Plato's Republic) but also the Byzantine hagiographical depiction of Jesus Christ's Resurrection qua Descent to Hades. The end of Dionysius' 8th Epistle (the Christian counterpart to Proclus) recalls this Byzantine icon and forms a narration framed as a vision that a pious man had. There are crucial features differentiating Proclus from Dionysius, and Eriugena's poetry (paschal in tone) helps in order to understand their ontological background and the eschatology they imply, as well as explain why Christ's "philanthropy" (love for mankind) is more radical than that of Proclus' Socrates.
\end{abstract}

Keywords: ataraxia; descent; Dionysius; Eriugena; eros; hierarchy; incarnation; Jesus Christ; love; mania; Proclus; resurrection; Socrates

\section{Introduction}

Perhaps the most famous descent in the philosophical literature stems from the Cave simile in Plato's Republic. ${ }^{1}$ Its Christian counterpart is not only Jesus Christ's incarnation ${ }^{2}$ but especially the Resurrection itself, which in Byzantine iconography is depicted as a "Descent to Hades". ${ }^{3}$ Despite the similarities one can find in the philosopher's and Christ's descents, there are also various differences. A basic difference is that, in the Christian case, the humiliation encapsulated in the descent is a characteristic of the Sun of Righteousness, i.e., of God himself. In Plato's case, the sun who illuminates the vision of the philosopher does not descend; it is only the philosopher who descends to the cave, functioning as a mediator between the under- and outer world, between the human and the divine, like eros in Symposium. What are the ethical consequences that the concept of descent in Neoplatonism and Christianity implies? In what follows, I juxtapose these two models by looking at some examples from the pagan Neoplatonic appropriation of the Platonic Cave simile found in Proclus' Alcibiades Commentary and from a Christian counterpart in Dionysius' 8th Epistle, coupled with relevant passages from Eriugena's poetry. The Eriugenian eschatology, to be found there succinctly expressed, illuminates the different ontological backgrounds between Proclus and Dionysius. A common denominator in these thinkers is the connection of descent with love.

I begin with a Proclean passage that I regard as the most exciting of the whole Commentary on the First Alcibiades:" "Socrates at any rate is full of the good and the beautiful and offers the young man communication in the virtues; he descends ( $\alpha \dot{\alpha} \tau \varepsilon\llcorner\sigma \iota v)$, as it were, to activity in relation to another, and proceeds from his inner life to a movement lower in

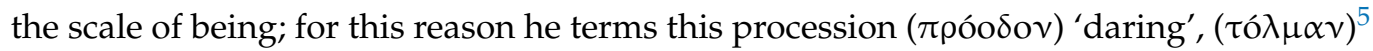
after the manner of the Pythagoreans, and manifests his forethought $(\pi \rho 0 \mu \eta \dot{\eta} \theta\llcorner\alpha v)$ for 
the young man; ... But because Socrates 'ventures ( $\tau 0 \lambda \mu \tilde{\alpha})$ to declare his own $\operatorname{mind}^{\prime},{ }^{6}$ he descends to an activity inferior to that which abides within him; since for divine lovers, to turn towards the inferior is at any rate venturesome; ${ }^{7}$ but nevertheless Socrates does descend, in order that like Hercules he may lead up his beloved from Hades, ${ }^{8}$ and persuade him to withdraw from the life of appearance... " 9

This passage is remarkable for many reasons. For one thing, it shows Proclus' wondrous (allegorical) sensitivity for recognizing Platonic patterns and schemes, such as the $\kappa \alpha \tau \dot{\alpha} \beta \alpha \sigma \iota \zeta$ into the Cave, as anticipated in the mythical background of versatile Greek culture. ${ }^{10}$ Moreover, the abovementioned parallel with Christ's descent to Hades is not difficult to make. ${ }^{11}$ Elsewhere, I have explicated the metaphysics and terminology of erotic providence (here surprisingly denoted by the central Neo-Pythagorean and Gnostic notion of "audacity" / $\tau \hat{\prime} \lambda \mu \alpha) .{ }^{12}$ I have also discussed how to square descending eros with the proper use of ascending eros as desire for the divine, ${ }^{13}$ as well as the Neoplatonic ideal of transcendent providence: ${ }^{14}$ this kind of providence excludes descent because it pertains to lower entities, say embodied souls, who, by being lower in the rank of being, exemplify their attenuated providence by descending, like Socrates and Hercules in the above passage.

\section{Proclean Ataraxia}

I would now like to draw attention to some problematic features of Neoplatonic erotic providence. ${ }^{15}$ These problems spring from certain ontological presuppositions (for instance, the pagan Neoplatonic notion of hierarchy) having their foundations in Platonic texts. ${ }^{16}$ For instance, the infamous episode of Symposium ${ }_{1}^{17}$ where Socrates abstained from having any sexual contact with Alcibiades, must have been of paramount importance to Proclus and is in line with other Platonic enunciations, such as that of the Form of Beauty, the end

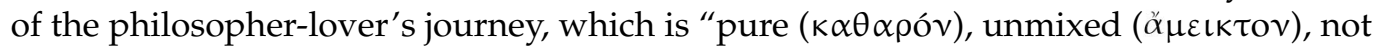
polluted by human flesh". ${ }^{18}$

In the context of the discussion as to why Socrates' guardian spirit allowed him to associate with Alcibiades, although it could foresee that the young man would not be finally benefitted from the Athenian gadfly, ${ }^{19}$ Proclus invokes several arguments ${ }^{20}$ and examples ${ }^{21}$ in order to conclude: "So Socrates also achieved what was fitting;, ${ }^{22}$ for all the actions of the noble man have reference to this: ${ }^{23}$ if he has acted, then, beneficently and in a divine manner, he achieves his end in his activity, even if that in him ${ }^{24}$ which admits of external activity also has not been perfected" ${ }^{25}$ Although the text is not fully clear, it seems safe to say that it is not for the sake of the recipient that providence (i.e., "external activity") takes place but rather the other way round: it is for the sake of its taking place that a (fitted) recipient must be found, since providence is necessarily an intentional activity. This seems to suggest that Socrates might not be so interested in Alcibiades' perfection for the sake of Alcibiades but only to the extent that the latter is expedient as a receptacle for Socrates' external and overflowing activity. In that way, Socrates' or his divine analogue's "affection" must be qualified, and all the more so since Alcibiades' failure of perfection does not seem to imply anything about Socrates' complete status. After all, Socrates does not need Alcibiades in order for the former to recollect the intelligible. In other words, Alcibiades assumes the place of a preferred "indifferent" for the Stoic-like sage Socrates. The Neoplatonic sage seems wholeheartedly sympathetic, so to speak, to the view expressed in the Stoic archer analogy: ${ }^{26}$ the preferred indifferent forms only a target so that the sage can perform a virtuous action, no matter whether the target is accomplished (e.g., the preservation of health), the actual target lying within the virtuous activity itself. ${ }^{27}$

My suggestion can be supported by another excerpt, where Proclus comments on a small phrase abstracted from Socrates' initial exchanges with Alcibiades: ${ }^{28}$ "The phrase 'so I persuade myself,' seems to me to show clearly that the divinely-inspired lover, if he sees the beloved suited for conversion to intellect, helps him, in so far as he is able; but if he finds 
him small-minded and ignoble and concerned with things below, he [sc. the lover] turns back to himself and looks towards himself alone, taking refuge in the proverbial 'I saved myself. ${ }^{29}$ For the persuasion and self-directed activity are indications of this knowledge (sc. the erotic) ${ }^{\prime \prime} .{ }^{30}$ From this description, it turns out not only that the divine lover is not in need of his beloved but actually that he is not very much troubled about the other person and his/her final perfection either. ${ }^{31}$ Of course, we should not lay too much weight on the slightly surprising use of the proverbial "I saved myself" because the lover is in any case, and regardless of the beloved's fate, already saved. We can exclude the egoistic accusation that the lover has used the beloved for the former's ascent and then stopped caring about his "ladder": the lover did not need the beloved right from the beginning. The beloved's failure to keep pace with him—or, in the words of the previous citation, the fact that "even if that in him which admits of external activity also has not been perfected" does not seem to have any impact on the tranquillity $(\alpha \tau \alpha \rho \alpha \xi i \alpha)$ of the lover's internal and self-directed activity.

Perhaps, then, the lover was not much interested in being providential for the sake of the beloved but rather for the activity's sake, since providence is necessarily an intentional activity. In this case, although the beloved is not a necessary requirement for the divine lover's self-realization, (s)he is reduced to a means for the manifestation of the lover's self-realization. Moreover, in our passage, the lesser importance of this instrumentality is evident in that the divine lover presumably can perfectly do alone with himself, as well. Thus, even if there were affection between the lover and his beloved, this must have surely been disinterested, on the lover's behalf. Of course, it is natural enough to turn one's back on someone who does not or cannot follow. Nonetheless, it is a question of whether we would like to posit that as an ethical ideal. To recap, so far I have given some examples in order to show that although altruism can be found in Proclus, who thus gives answers to Gregory Vlastos' (or Anders Nygren's) egoistic accusations of Plato, a peculiar kind of instrumentality might arise in Proclus' framework, too.

\section{Dionysian Mania}

Now, let us move to Dionysius' more frugal and humble metaphysics in order to pursue Neoplatonism's comparison to Christianity. Once more, elsewhere I have discussed how Dionysian erotic providence likens and differs from Proclus' version and have explained the thesis with which I started this paper, i.e., that in Christianity ${ }^{32}$ it is God Himself who descends, not a secondary being in the ontological scale. ${ }^{33}$ Hence, the metaphysics of transcendent providence is quite different in Dionysius, despite the identity of terminology with Proclus, as I show in yet another paper. ${ }^{34}$ For my present purposes, I do not refer to the incarnation itself or the resurrection but to a recounted vision that recalls not only Jesus Christ's descents but also the Bible's Parable of Judgement. ${ }^{35}$ It also has some similarities both in terms of text and ideas with Socrates' aforementioned descents and especially the Hercules simile that Proclus uses. I do not argue, though, that Dionysius consciously draws or alludes to this specific chunk of Proclean text, giving his Christian version of descent, although this might be plausible too. ${ }^{36}$

The 8 th Epistle is the longest ${ }^{37}$ and most enticing of the Dionysian ten Epistles. As a distinctive part of the Dionysian Corpus, these letters form a whole that is hierarchically structured: from the first to the last epistle, we see an ascending ladder of recipients in the ecclesiastical hierarchy (starting with a monk and ending with a theologian). The hierarchy breaks only in the 8th Epistle, whose recipient is the monk Demophilus (a lover of "the many", like Alcibiades). The reason is that, in this way, Dionysius mirrors and draws our attention to the content of the letter: ${ }^{38}$ why and how one should (not) break the hierarchy. Demophilus judged that a priest, by being meek ${ }^{39}$ towards a sinner (full of penitence), had sinned and should not enter the altar. Dionysius criticizes Demophilus in two ways: first of all, Jesus himself was meek and called us to love even our enemies. ${ }^{40}$ Hence, Demophilus' stance against the priest was false because it was bereft of meekness, while presumably the 
priest was not mistaken at all. The second argument is that even if the priest were wrong, Demophilus should not violate the hierarchy and criticize a higher member of the Church He should let the priest's peers or higher members do this for two reasons: (a) The closer in the hierarchy we get to God, the more light one receives from God in order to illuminate the others, too. The good judgment and, if needed, the intervention by the high members of the Church seems secured. (b) Even if a hierarch is unsuccessful in this work, though, it is safe to wait that some other illumined member will intervene in order to align things with the will of God. As a crown to this discussion, which structurally parallels the final myths of Platonic works, such as Republic (Book X) and Gorgias, ${ }^{41}$ the letter ends with a vision $^{42}$ that a pious man in Crete, ${ }^{43}$ presumably a priest named Carpus, had. ${ }^{44}$

This story illustrates both of Dionysius' above points by reminding us how the top of Hierarchy, the humble and meek Christ, acts. The context is similar to that of Demophilus' framing story. Carpus was upset by the sinful behaviour of two men ${ }^{45}$ and envisaged them as being in a chasm, in fact, an image of Hell since serpents were trying to take down the two sinners. He was delighting in this because it was presumably a just punishment. However, the manic lover of mankind did not think so. When Carpus looked up again, "Jesus, moved to pity $(\dot{\varepsilon} \lambda \varepsilon \dot{\eta} \sigma \alpha \nu \tau \alpha)$ at what was happening, had risen $(\dot{\xi} \xi \alpha \vee \alpha \sigma \tau \tilde{\eta} v \alpha \iota)^{46}$ from his supercelestial throne, and descending ( $\kappa \alpha \tau \alpha \beta \alpha \gamma \tau \tau)$ to them He reached out a helping hand, the angels accompanying Him to help out by taking hold, one on each side of the two men. And Jesus said to Carpus: 'So, with your hand already raised up ${ }^{47}$ strike against me. For I am prepared, even again, to suffer for the sake of humans, who are in the process of recovery ( $\alpha \vee \alpha \sigma \omega \zeta \omega \mu \varepsilon \varepsilon v \omega v)$. And this is dear to me, lest other people should be led to sin. But look whether it is well to exchange the abode next to God and the good and man-loving ( $\varphi \iota \lambda \alpha v \theta \rho \omega \pi \omega \nu)$ angels for that in the chasm with the serpents."'18

This remarkable experience reveals many similarities with the (Neo-)Platonic antecedents I discussed before. For example, like Hercules, Jesus descends to a chasm that reminds either of Hell or Plato's fiery Cave ${ }^{49}$ in order to save two persons, as in the ancient Greek myth (with Perseus and Pirithous). What is more, as in the Icon of Resurrection with Adam and Eve, Jesus Christ gives his hand to the sinners, which is a symbol of man's potentiality to become god, since God became man. ${ }^{50}$ However, does not man's godlikeness $^{51}$ threaten the hierarchy? The Epistle shows us that an upwards violation of the hierarchy might be forbidden. However, a downwards violation of the hierarchy is a product of the hierarchy itself! Jesus Christ descends in order to take upon Him the sins of the two people. His descent is not an attenuated image of divine providence, as in Socrates' or Hercules' case in the Proclean framework, but the divine and manic erotic providence par excellence. Thus, the hierarchy is not static but dynamic: it exists and persists in so far as its members can descend in order to help and save those that are remoter from the Sun, the source of Light and Life, so that they become as "sun-like" as possible. ${ }^{52}$ Sign that one has become more godlike is his/her identification with the ones in need, qua descent to their level, as Christ does both in Carpus' vision and in the Parable of Judgement. ${ }^{53}$ This is why, in sharp contrast to Christ's helping hand, Carpus' hand against the sinners ended up being against Christ himself. ${ }^{54}$

To sum up so far, what is the practical outcome of the juxtaposition between these pagan and Christian versions of descent? We have seen that, according to Proclus, if the divinely inspired lover finds the beloved "small-minded and ignoble and concerned with things below, he turns back to himself and looks towards himself alone ... " 55 Dionysius' Christ sees this in another way: "Here I am, ready once again $(\alpha \tilde{u} \theta \iota \varsigma)$ to suffer for the salvation of man and I would very gladly endure it if in this way I could keep men from $\sin ^{\prime \prime} 56$-although admittedly this is very difficult. If descent is not only a remote by-product of providence as in Proclus' Neoplatonism but the essence of loving, ecstatic and kenotic providence itself, then the divine lover will never settle in order to "turn back to himself and look towards himself alone". Resurrection qua descent to Hades is a fact that is repeated every "now and forever". ${ }^{57}$ 


\section{Eriugenian Eschatologia}

It is, of course, up to us to choose from the two abovementioned paradigms the erotic modus vivendi we would like to imitate. However, what are the ontological "mechanics", so to speak, of this differentiation? Why and how can Dionysius' view be more realistically optimistic than the Proclean one? Is it only about the number of repetitive attempts to help one who is in need? To answer these questions, I turn to John Scot(t)us Eriugena. I adduce evidence from his poetry, ${ }^{58}$ part of it written late in his life. The reason I use this particular mini-corpus is that it thematises descent to Hades and resurrection in a way unprecedented in Eriugena's oeuvre and also because, in these poems, Eriugena, in a succinct manner, touches on themes that are explored in much lengthier ways in Periphyseon. Thus, before getting into the answer to the questions posed above, as a way of getting acquainted with the tone of Eriugena's poetry, let us see some moving Eriugenian illustrations of the motive of descent, which are comparable to images we have already discussed in the previous sections.

First of all, let us begin with the terminology. Eriugena uses cognates of the term "descent" (descensus/descendo) in order to express the fact of incarnation, already mentioned as a prominent species of Christian descent in the introduction: "What mind, what power, what created wisdom of heaven/can describe the descent (descensum) of the Word into the flesh". ${ }^{59}$ Correspondingly, Christ's unceasing care for the salvation of mankind (i.e., of the crown of creation), which we witnessed in Dionysius' Epistle, is here transposed to the phase (or seen from the point of view) of creation; if the "logoi" of beings exist in and through the Son, then creation has a special relation to "theophany", ${ }^{60}$ and, hence, Eriugena declares that "Christ, who is always born (semper natus), sees ${ }^{61}$ all things created". ${ }^{62}$

As already stated, still more than in the case of incarnation, the consummation of God's love $^{63}$ for His beloved creation is found in Jesus Christ's resurrection; Eriugena's praise for Easter is scattered throughout his poems ${ }^{64}$, and we may well declare that his poetry is paschal in tone. ${ }^{65}$ Consider as an example the following epigram, written originally in Greek: "Behold the resurrection of him who was buried in deep death/and the Church" 6 cries out 'alleluia' ${ }^{67}$ to the living Christ". ${ }^{68}$ It is within this context that we find plenty of references to Hades' imagery, ${ }^{69}$ with elements of it recalling the pagan similes mentioned above, ${ }^{70}$ e.g., the existence of prisoners ${ }^{71}$ in a cave ${ }^{72}$ who are set free. ${ }^{73}$ However, having granted that Dionysius alludes to the descent of the resurrection in his 8th Epistle, it is true that Eriugena's paschal imagery seems to make a shift in underlining the more straightforward upward movement of Jesus Christ's resurrection, i.e., ascent, ${ }^{74}$ which thus becomes the corresponding answer to Christ's descent in the incarnation. However, Eriugena does not deny that, in terms of this imagery, in order for Christ to be able to rise from the dead in Hades, he would have needed to descend even lower than the level of the alive human beings. ${ }^{75}$ In other words, a necessary ${ }^{76}$ precondition of the resurrection is not just Jesus' birth but also His death. ${ }^{77}$ After all, when Paul, echoed by John, ${ }^{78}$ reminds us that the one who has ascended is the same one who descended, ${ }^{79}$ he mentions a descent ${ }^{80}$ "to the lowliest places of earth" ${ }^{\prime 1}$ which, in terms of this spatial imagery, is to be interpreted as a descent to the realm of Hades. ${ }^{82}$ Thus, for all his rhetorical and poetical choices, as well as philosophical emphasis, Eriugena does not really deviate from Dionysius' theology. ${ }^{83}$ What is more, Eriugena is in line with a key feature of the 8th Dionysian Epistle, i.e., descent as humility. He is not repeating Carpus' mistake of ascribing to all others the responsibility for the ever-recurring crucifixion of Jesus Christ (through our deeds and thoughts against our fellow humans), but he is ready to acknowledge the trespass of Adam in his own life: "Almighty one, have pity on me (miserere mei) in my grief/for I am the cause of my own sorrow". 84

Moreover, it is such a stance, which is bereft of sheer moralism, that leaves room for the ontological hope of one's personal salvation, qua eternal life with the lover-andbeloved Christ ${ }^{85}$ (i.e., qua Paradise ${ }^{86}$ ), ${ }^{87}$ given that Christ's descent to Hades (with His consequent resurrection) opened the gates of Hades for all without exception, as Eriugena 
is keen to note. ${ }^{88}$ This is precisely the point that answers the questions with which I started this section. Let us see why and how through the verses of one of the most impressive poems in the Eriugenian collection, Carmen 8: “ . . Christ our Redeemer/ . . because your provident power desired that nothing of man should perish/It embraced our nature $(\Phi \mathrm{I} \Sigma \mathrm{IN})$, now free of every taint/In your power is our nature $(\Phi \mathrm{I} \Sigma \mathrm{I} \Sigma)^{89}$ fully restored (renovatur) ${ }^{90}$ henceforth/And a potent antidote, ${ }^{91}$ prepared to help all men/Wards off divers ills from those who drink it $/{ }^{92}$ While rightly permitting those to perish who refuse it/For God, compelling none to have life $^{93}$ against his will/Expels no one of good will from the threshold of the light/Inviting all, ${ }^{94}$ he abandons the former, the latter he assists ${ }^{95} .96$

The thesis that the possibility of salvation ${ }^{97}$ is granted to the whole humankind is reiterated here, expressed through the term "nature", i.e., via the human nature of Christ, who, in virtue of His two natures (or substantiae), is consubstantial both with the Father and with humanity, that is, with each and every human being (through His mother, the Theotokos $\left.{ }^{98}\right) .{ }^{99}$ Does this mean preordaining or violating each person's freedom? No, says Eriugena, succinctly expressing the experience of the church and the (Greek-speaking) Patristic tradition, as well as a ubiquitous master-theme of the final Book ${ }^{100}$ of his epic Periphyseon: ${ }^{101}$ Christ does nothing against our own will, even if this means a human existence's ontological "divorce" from its manic lover and bridegroom. ${ }^{102}$ Mentioning life in the above passage, Eriugena is speaking in eschatological terms, bringing in our minds (once more) the Parable of Judgement, as well as that of the Wedding Feast. ${ }^{103}$ He means the true life without death, i.e., living together with the source of life, or Life itself ${ }^{104}$, in the day to come. Jesus Christ's resurrection as restoration, "renovation" and immortalisation of the perfected human nature is precisely this gift to everyone; ${ }^{105}$ however, according to the exercise of one's freedom in his/her earthly life, ${ }^{106}$ some people will have opted for a future wedding with Christ ("deification"), ${ }^{107}$ whereas others will have practically chosen Hell («Kó $\lambda \alpha \sigma \iota \varsigma »)^{108}$ in the sense of being (forever far away or) divorced from Christ. ${ }^{109}$ In each case, the decisive factor is not one's perfection or sinlessness (only God is perfect) but the humility of acknowledging one's own Fall and asking forgiveness from the Father, as in the Parable of the Prodigal Son, ${ }^{110}$ a stance we have already seen characterizing both Eriugena and Dionysius.

Furthermore, Eriugena is in accord with Dionysius in so far as salvation is a matter of

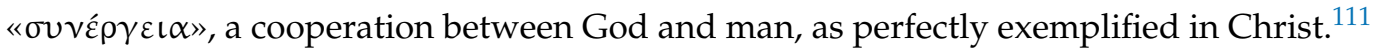
Jesus Christ resurrects human nature, but it is up to us whether we want to open ourselves (i.e., our nature) to the others, as Christ did (viz. live in paradise), or stay egocentrically closed to ourselves (hell). On the other hand, Proclus' paradigm hints rather to an asymmetrical relation: Socrates is like a sun radiating, ${ }^{112}$ and it is completely a matter of Alcibiades' receptivity, i.e., his freedom of choosing to (be able to) receive Socrates' bestowals of goods. Socrates (for all his good-like will) is not able to save Alcibiades if Alcibiades refuses so. ${ }^{113}$ The subtle but cardinal difference with Christ is that, via His descent, qua incarnation and resurrection, Christ has already saved (i.e., He has perfected and immortalised) human nature, ${ }^{114}$ and it is up to us to choose whether we want to partake in our salvation (qua modus vivendi with Christ) or not. ${ }^{115}$ This Eriugenian ontological optimism, grounded in the synergistic model of Christ (rather than of Socrates), is translated in the unceasing attempt of Christ to elevate human nature, as we saw in the context of Dionysius' 8th Epistle, which contrasts the questionable ethical consequences of Socrates' ataraxia and impassivity that I drew from the Proclean excerpts of the Alcibiades Commentary. ${ }^{116}$

\section{Conclusions}

To recap, my final section, based on Eriugena's poetry, enabled us to review some points where Christianity has surpassed Neoplatonism and accounted for Dionysius' optimism (exposed in Section 2) when contrasted with the Proclean relation of Socrates and Alcibiades (illustrated in Section 1): Jesus Christ's resurrection, qua descent to Hades, 
has made immortal the human nature common to each and every human being and has paved, as well as established, the way for the modus of paradise life qua love between lover and the beloved(s). It is only up to the persons to decide for and during their own lives (even in their last minute) if they want to follow this ascending path or not. Whether the response is the one that Alcibiades finally gave or that of the thief who was crucified on the right side of Christ, ${ }^{117}$ we can be assured that Dionysius' and Eriugena's God is like the father of the prodigal son: he does not sit at his home (or just observe whether his son is arriving, as the Proclean Socrates would at best do), but he is always waiting and ever ready, when seeing his son coming, to rush toward his side in order to embrace him ${ }^{118}$ (however sinful he was), bring him back home and give him a ring, ${ }^{119}$ as well as a new garment, ${ }^{120}$ for, from an eschatological perspective-which we have already witnessed in Eriugena's vision - in contrast to the envious brother ${ }^{121}$ (a persona for Dionysius' Carpus), that son was spiritually resurrected ${ }^{122}$ because he descended to his Hades: he "was dead and is alive again". ${ }^{123}$

Funding: This research received no external funding.

Institutional Review Board Statement: Not applicable.

Informed Consent Statement: Not applicable.

Data Availability Statement: Not applicable.

Acknowledgments: Part of the introduction was based on a tiny part of (Vasilakis 2019a); part of Section 2 drew on (Vasilakis 2021a, partly chp. 2.1.5), a well as (Vasilakis 2021b, two final sections). Section 3 is based on the relevant part of the paper I read at the Workshop on Platonism and Christian Thought in Late Antiquity (Oslo, December 2016, entitled "Neoplatonic Descent: A Proclean Example with a Dionysian Counterpart"). I thank everyone who has benefitted me with his/her feedback on all these occasions, as well as Eva Anagnostou-Laoutides, George Steiris, Andreas Athanasakis and two anonymous reviewers for their thoughtful comments on drafts of this paper.

Conflicts of Interest: The author declares no conflict of interest.

\section{Notes}

1 In the opening of Book VII of Resp. 514a1ff.

2 Panagiotis Pavlos has reminded me that in Byzantine art Christ's birth is always depicted in a cave. See also (Skliris 2014, pp. 37b, 38a) (available online: https:/ / www.pemptousia.gr/analekta_issues / Analekta_DEC_2014_Logos-Sarx_fin/HTML/mobile/ index.html\#p=37, accessed on 6 August 2021).

3 The depiction of Christ in Hades (see also Matthew 12:40 with more on prophet Jonah's prefiguring in Luke 11:29-32) is not unknown in the West, too, since it survives in the various representations of "Christ in Limbo", although it still substantially

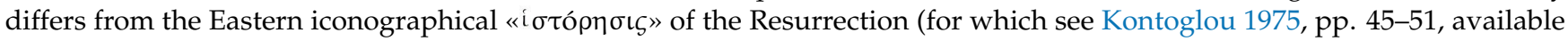
online: http: / / www.apostoliki-diakonia.gr/gr_main/catehism/theologia_zoi/themata.asp? cat=art\&NF=1\&main=texts\&file= 2.htm, accessed on 31 July 2021). For instance, in the latter case, Christ, the New Adam, is depicted as raising up Adam and Eve, i.e., the Old Man (cf. infra, n. 11), whereas in the former case, the scope is narrowed down to the people that just lived before Christ but would be and were still potentially convertible by Christ's preaching. On the whole, see (Loerke 2003).

$4 \quad$ Henceforth: in Alc. (following the edition translation of Proclus 2011).

5 Alternatively: "audacity".

6 Cf. [Plato], Alc.I 104e5-6.

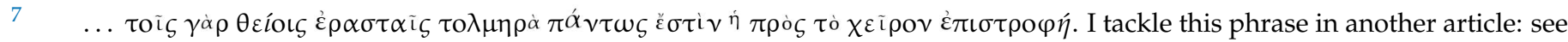
the reference infra, in n. 12.

8 For attestations of this remarkable mythic image in prior Greek (and posterior secondary) literature, see the references provided ad loc. by O'Neill, n. 274 and (Proclus 1985, n. 5 in p. 202), especially to pseudo-Apollodorus, Bibl. II.124,1-7, with Frazer's invaluable scholarly n. 64 ad loc. and his n. 62 on ibid., II.123,3. The system of reference used here is that of R. Wagner in his Teubner edition and exhibited in the online Thesaurus Linguae Graecae (TLG), although O'Neill is using only the traditional divisions, adopted by J. G. Frazer in the references of his "Loeb" edition translation which features at the Perseus Digital Library. This is why O'Neill gives a general reference to Bibl. II.5,12/Perseus = II.122ff./TLG, which starts recounting Heracles' twelfth labour. Now, whatever the system adopted by Segonds, his reference to Apollod. Bibl. I.21ff. seems intractable, unless it is a complement to the Library, i.e., Epitome, 1,21ff./Loeb/Perseus = 21ff./Teubner/TLG, where in §24 we have a short mention of our 
story; cf. also Frazer's n. 1 ad loc. What is more, Segonds' other reference to Plutarch's Thes. 30ff. (V.Par. esp. 31.4,1-35.3,5) alludes only to a "dull rationalistic version of the romantic story", converting "Hades into a king of the Molossians or Thesprotians, named Aidoneus", as is duly noticed in Frazer's aforementioned n. 64).

9 In Alc. 132,10-16 \& 133,6-13.

10 Note that, in this story, Perseus and Pirithous are bound (if not in fetters) like Plato's prisoners. It is also characteristic that, in the course of the explication of the Cave simile, Socrates asks in Resp. VII.521c1-3: "Do you want us to consider now how such people will come to be in our city and how-just as some are said to have gone up ( $\alpha v \varepsilon \lambda \theta \varepsilon i v)$ from Hades to the gods-we'll lead

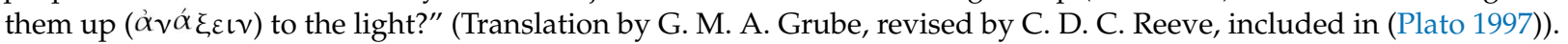

See (literally!) the aforementioned (n. 3) Byzantine iconographical type of Resurrection, which depicts Christ as holding Adam and Eve's hands because He raises them up from the tomb of Hades. Cf. ps-Apollodorus Library 124,6: $\lambda \alpha \beta$ ó $\mu \varepsilon v o \zeta$ [sc. ó

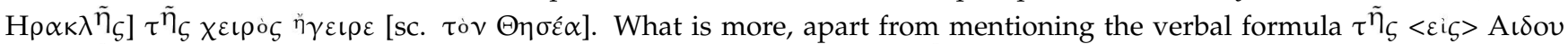
$\kappa \alpha \tau \alpha \beta \alpha \alpha_{\sigma \varepsilon} \omega \zeta$ (ibid, II.123,2 Wagner), two verbal cognates of the word $\dot{\alpha} v \dot{\alpha} \sigma \tau \alpha \sigma \iota \zeta$ are used (124,5, $\omega \zeta \dot{\alpha} v \alpha \sigma \tau \eta \sigma o ́ \mu \varepsilon v o l ; 124,7$, $\alpha v \alpha \sigma \tau \tilde{\eta}_{\sigma \alpha \iota}$ ). Reasonably, Frazer translates as "raise from the dead" (in the first instance; in the second, just "raise up") a meaning which already exists from Homer onwards, as is attested by LSJ, A.I.3\&B.(I.) 3 ad lem. (For the most common sense of "make to stand up, raise up", see ibid., A.I. [1].) However, exactly due to the strong Christian resonances, we might be careful in that, in our context, we (mythologically) speak of a literal "place", the underworld, from which our two heroes have the opportunity to escape if they are freed from their bonds and hence stand up. Of course, it was through such imagery that the word $\alpha v \alpha \dot{\alpha} \tau \alpha \sigma \iota \varsigma$ came to have its standard meaning of Christian "resurrection" (sc. from the deads). See also infra, nn. 46, 36. Most notably (Vasilakis 2019a); the present paragraph, as well as the previous one in my main text, is based on this article of mine, to which I refer the reader for annotation, further references and relevant discussion (including translation issues). See (Vasilakis 2021a, pp. 67-111). See also (Vasilakis 2017, pp. 408-9).

See for more detail (Vasilakis 2021b, pp. 93-95) (available online as an open-access publication at https:/ / press.nordicopenaccess. no/index.php/noasp/catalog/book/133, accessed on 7 August 2021).

16 I treat this Platonic legacy of Proclus extensively in chp. 2.1.5. of (Vasilakis 2021a, pp. 84-91). There I give ample references not only to Platonic texts but also Proclean ones (In Alc. and Elements of Theology). Characteristic, in order to understand what divine "undefiled" and "unmixed" providence is, is proposition 122 of the Elements; see also the reference in n. 14 above. See Plato, Symp. 217c4ff.

Cf. the whole characterization in ibid., 211e1-3; cf. also ibid., 203a1-2: “Gods do not mix with men". (Transl. by A. Nehamas and P. Woodruff included in Plato 1997). My characterization of Socrates stems from Plato's Apology 30e5.

For example, the classic one by which the failure to receive the divine and good bestowals is attributed to the receiver's inability. See Proclus' related simile with the sun and what can share in its light in In Alc. 90,22-91,6 (with O'Neill's n. 213). See another classic example of Laius, father of Oedipus, and the renowned Delphic oracle in In Alc. 91,10-15, with O'Neill's n. 214. The translation includes here content (except for "also") that, in Greek, is supplied by Westerink in angle brackets; see his apparatus ad loc. For an issue regarding manuscript reading and translation, see $\mathrm{O}^{\prime} \mathrm{Neill}$ 's justification in n. $216^{*}$. For some difficulties in the Greek here, see (Vasilakis 2014, p. 149, n. 195) (available online: https:/ / kclpure.kcl.ac.uk/portal/en/ persons / dimitrios-vasilakis(1cc3c059-afb7-4606-9e25-24fe6efd6eb1)/theses.html, accessed on 7 August 2021).

In Alc. 139,18-140,2. For a full explication of various detailed interpretive issues regarding this passage, see (Vasilakis 2021a, p. 132, nn. 211-14). Imagine a very good teacher or lecturer who, despite delivering qualitative talks, is not interested in whether his/her audience understands or is benefited by him/her. Defined up to Dionysius' real time (early 6th cent.) by the first four Ecumenical Councils.

Cf. (Vasilakis 2021a, p. 158).

Cf. (Vasilakis 2017, passim).

See Matthew 25:31-46.

Even in the case that Dionysius is directly drawing on primary sources regarding the myth (see n. 8 above), he should be aware of Proclus' use, if we consider the plenitude of his Proclean references, not least to the Alcibiades Commentary. Regarding 
Christianity's treatment of Hercules as prefiguring Christ, see (Heidl 2020, pp. 70-74), with relevant bibliography, although there is no mention of the episode to which Proclus refers; instead, Euripides' theme of Hercules' descending to Hades in order to bring back to life Admetus' wife, Alcestis is mentioned (for which, see Hard 2004, pp. 151-52, with relevant references in the notes of p. 621, as well as 8; a version of the story, without Hercules, though, is first mentioned by Plato in Phaedrus' speech in the Symp. 179b4-d2).

See in the critical edition of (Pseudo-Dionysius Areopagita [1991] 2012, pp. 171,1-192,2) (=1084A-1100D according to the PG pagination).

Cf. (Hathaway 1969, p. 65) and Paul Rorem's n. 1 in (Pseudo-Dionysius 1987, p. 261). As it is clear, though, from what follows, I do not espouse Hathaway's hermeneutics of suspicion, to say the least, despite his interesting observations.

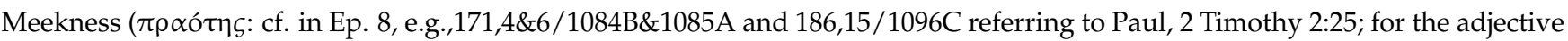
$\pi \rho \tilde{\alpha} \mathrm{O}$, see, e.g., Ep. 8.171,10/1085A) is a presupposition of love, as John Climacus notes in Scala paradisi (Ladder of Divine Ascent), $\$ 24.980,21$ (PG); cf. ibid., 981,6. Indeed, the last Dionysian epistle is addressed to the Evangelist of love, St John the Theologian. On this, see also (Vasilakis 2014, pp. 246-67) with n. 135; (Vasilakis 2021a, p. 157 with 180, n. 147). Cf. Matthew 5:44 implied in Ep. 8.\$1.172,8-9\&10-11/1085B.

41 See also the Phaedo ad fin. and the remarkable (although sometimes exaggerated) Platonic parallels that Hathaway (1969, pp. 93-97) observes. (Hathaway does not mention the Phaedo but instead underlines the Phaedrus myth.)

So too in Plato's Republic: the Cave simile is recounted within the great simile of the polis, which, in its turn, serves as a simile for the soul.

A question remains as to why this place, if Carpus is a fictitious figure, was chosen. Note, though, that Crete features in the frame of Plato's Laws. See Ep. 8.§5.188,6ff./1097Bff.

Remember Theseus-Pirithous in Proclus' image above.

It is not accidental that the verb used here is cognate with the word used for Christ's resurrection $(\alpha v i \sigma \tau \alpha \mu \alpha \iota)$. See also n. 11 above.

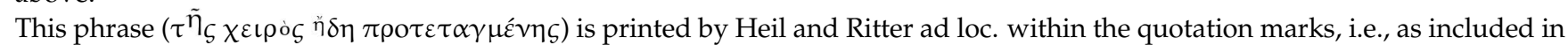
the words of Christ, while Hathaway takes it as part of the narration introducing Christ's citation. I tend to agree with the editors (as well as Luibeid in Pseudo-Dionysius 1987) because otherwise Christ's first word, the imperative $\pi \alpha \tilde{\varepsilon} \varepsilon$, would be abrupt, without any foregoing preparation in the text (save for the participle $\kappa \alpha \tau \alpha \pi \alpha i$ o $v \tau \alpha \varsigma /$ "beating" in 1.4, which, however, refers to some other men cooperating with the serpents against the two men). In Hathaway's rendering, it is natural to understand that the hand referred to is that of Christ in 11.12-13; however, the alternative option makes for a very nice contrast between Carpus' and Christ's stances, which is in accord with the general intention of this passage. That said, if Dionysius is a very careful author, who, as I argue in (Vasilakis forthcoming), employs Platonic literary techniques, then it might be that the positioning of this phrase has been deliberately ambiguous in order for the reader to have to delve deeper into this remarkable passage. This characteristic goes back to Heraclitus (see, e.g., the ambivalent position of $\alpha \varepsilon$ $\iota$ in B.1,2 DK), who is criticised on these grounds by Aristotle in Rhet. 1407b,12-18.

Ep. 8.\$6.191,11-192,1/1100C-D. (Translation by Hathaway 1969, modified by me.)

In its turn, this is reminiscent of the wondrous chasm $(\chi \alpha \tilde{\sigma} \mu \alpha)$ at the beginning of Gyges' story in Resp. 359d4 (although the function of $\kappa \alpha \tau \dot{\alpha} \beta \alpha \sigma \iota \varsigma / \dot{\alpha} v \dot{\alpha} \beta \alpha \sigma \iota \varsigma$ does not exactly map unto what is at stake in the Cave simile). Note also that in Republic's eschatological myth of Er, Plato writes of two $\chi \alpha \dot{\sigma} \sigma \mu \alpha \tau \alpha$, one pertaining to earth, the other to heaven; cf. ibid., $614 \mathrm{c} 2 \& \mathrm{~d} 4$.

Cf. Athanasius the Great, De incarnatione verbi 54.3.1-2 (Kannengiesser). For some other references, see (Vasilakis 2016, pp. 108-9, n. 30).

Cf. both Plato, Theaetetus 176b1-3 and Genesis 1:26-27.

Precondition is an internal healthy hierarchy. See on the whole (Vasilakis 2019b) and in the specific context the relevant references in ibid., 195, n. 77.

53 Cf. esp. Matthew 25:40\&45. This is also the gist of a vision of Christ that St Symeon the Stylites had, as well as God's famous exhortation to St Silouan the Athonite: "Keep thy mind in hell and despair not". Cf. (Sophrony 1999, p. 427) (for the first case and for the second:) 42/208-13 (e.g., 212)/430. In fact, St Silouan helps us understand that the coda in Christ's words (reminiscent in spirit of Matthew 25:41) is not meant to threaten Carpus with condemnation immersed in wrath but to remind him of the precious ascesis that leads to meekness and consequently love, i.e., humility encapsulated in the ongoing "meta-noia". See above $n .47$ regarding the interpretation of this imagery.

55 In Alc. 139,20-22; cf. above n. 30.

56 For literary reasons, fitting better the atmosphere of this paragraph, I use here the translation of Luibheid for a citation of a text (Ep. 8.§6.191,15-7/1100C) that I quoted before within a longer excerpt (based on Hathaway's translation); cf. n. 48 above. Although Luibheid is not attentive to the grammatical-syntactical detail of the Greek, the sense here remains unaltered compared to the previous translation used. 
For the Latin text I use, (Iohannis Scotti Eriugenae 2020, henceforth Herren-b), while for the translation, (Iohannis Scotti Eriugenae 1993, henceforth Herren-a).

59 Carm. 25, 11.67-68. Note that in the following line (69), recapitulating the two foregoing lines and paving the way for an inverted analogy (between the descent of the Word to flesh and, hence, the ascent of the flesh in the highest), the expression "lapsus ad ima" (rendered as "fell to fields below") has no negative connotations, as it could have in the context of Adam's Fall. The other terminological instance of "descent" (in the participle) appears in a phrase of similar form; see Carm. 2.19: O mons virtutis, descendens carnis ad ima.

In the background of this second division of nature (which both is created and creates), is, of course, Maximus the Confessor, and the sense here is not pantheistic but rather "panentheistic" (cf. a Periphyseon reference by Herren-a, 141 on Carm. 5.5-6); see also the interesting discussion of (Wood 2018, touching on interpretive issues regarding Dionysius, too). Eriugena wrote also a poem to preface his translation of Maximus' Ambigua: Carm.22; see esp. 11.11-9 and cf. the first comment in Herren-a, 154.

The verb "see" ("videt") here has rather the sense of "oversee", i.e., be providential of (or "provide for"). Cf. also the parallel usage regarding creation from Periphyseon cited in Herren-a, 141.

Carm. 5.8; cf. also the preceding 1.7. As if from a more existential mood in (the Epistles of) Dionysius we have moved to a more ontological mode in Eriugena (although, of course, both imply one another).

It is true, though, that words for "love" (amor or caritas, $\check{\varepsilon} \rho \omega \zeta$ or $\alpha \gamma \alpha \dot{\alpha} \pi \eta$, etc.) are not used in the poems. However, one certainly cannot deny that what is described in a major part of them, i.e., Jesus' workings, is an expression of God's love (or Love Himself, as well as an illustration of Eriugena's corresponding love).

See, for instance, Carm. 1.7-8\&17-44. In 11. 29-34, there might be references to Dionysius' Epistle 7 (the famous sun eclipse, while the mention of the two thieves, crucified along with Jesus, might also be a reference to the two sinners in the coda of Dionysius' Ep. 8). The frame of the poem is the comparison between Homer's (as well as Virgil's) and God's epic sagas in order to extol the greatest "warrior" (Carm. 1.39: ОП $\Lambda \mathrm{I} \mathrm{TH} \Sigma$ —of love, though), i.e., Christ, (His greatest win being against Hades/Death; cf. also Carm. 7.13. Here we may find another parallel with Hercules drawing on the information of $n$. 36 above).

See, e.g., Carm. 3.1ff., e.g., 11. 25-60, esp. 52: ... Pascha novum ... . Herren-b, keen to note also the political dimensions (p. xli), mentions the possible occasions of participating in an Easter liturgy (p. xl).

Surprisingly, the word in the original Greek for "Church" here is Пvó , i.e., the meeting place of the ecclesia of demos (assembly) in ancient Greek democratic Athens! Cf. also Carm. 2.13 (with Herren-a, 137 ad loc.) and Herren-b, lxvii. I would like to pursue consequences of this kind of reference in a future paper.

In fact, the Greek here has $\mu \varepsilon \lambda \delta \delta \delta \eta \mu \alpha(\mu \varepsilon \lambda \omega \delta \delta \eta \mu \alpha)$, i.e., melody/song/tune.

Carm. 13. (1-2). This laconic and with profound happiness poem has something from the succinct but grand and laudatory

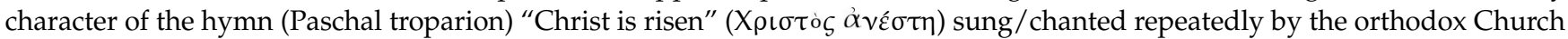
from Easter Sunday until the feast's « $\dot{\alpha} \pi \delta ́ \delta 0 \sigma\llcorner\varsigma, »$ forty days later. Cf. also in parallel Carm. 5.39-40.

See, e.g., Carm. 9.5/7/52.

Of course, at least for the case of Plato, the similarities must be indirect due to the scarcity (of Latin translations) of Platonic works (such as Republic) in Medieval West, save for Chalcidius' (partial) translation of the Timaeus (referred to in Carm. 3.7-8, according to the Index Fontium of Herren-b, 173).

Cf. Carm.6.20 (captivi/prisoners) and 23 ("retinacula loeti"/bonds of death), as well as Carm. 7.5-6.

72 Antro/aeternae mortis: Carm. 7.17-8.

73 Cf. e.g., ibid., 1.17 and Carm. 3.59-60. Here we have a difference already marked between the Cave and the Hercules similes, since (in most versions of the story) Hercules is successful in his labour (not included in the famous group of the twelve), whereas Plato's freed prisoner meets the fate of Socrates (cf. Resp. 517a4-7). In Christ's case, if we take Plato's prisoners as the equivalent to most contemporaries of Jesus (and more generally, us, human beings), the end of Jesus' earthly life was/is similar to that of Socrates. However, if we move to a deeper level (both figuratively and literally) and compare Plato's prisoners with the dead (not only the already dead ones but with the human nature in general under the dominion of death), then Christ's case has more than a happy end. The paradox of the juncture of these two levels, since it is through Christ's unjust death that He deserves to be resurrected, is well encapsulated in the aforementioned Paschal troparion (in n.68: $\left.\theta \alpha v \dot{\alpha} \tau{ }^{\omega} \theta^{\prime} \dot{\alpha} v \alpha \tau \sigma v \pi \alpha \tau \eta \tilde{\sigma} \sigma \varsigma\right)$ ) and echoed by Eriugena, e.g., in Carm. 9.29-30 (see also ll. 10-11/14-6/19-24): “The Lord who is the death of death rose living into heaven and ...". Cf. also Herren-a, 147 ad loc. and see the continuation in my main text for consideration of the Proclean and Dionysian paradigms. Cf. Carm. 7.15 (although only the verb "ascendit" is used, not the noun "ascensus").

Cf. Carm. 22.36: "In an octave he descended (subiit) to the seals of the ancient law" (my emphasis), along with the gloss of Herren-a,155 ad loc.: "A reference to Christ's suffering and death as prophesied in the Old Testament. This took place in the 'octave' between Palm Sunday and Easter Sunday". Moreover, also in the citation of n. 77, infra, the "battle" with/in Hades for three days during Christ's death—which marks the gift to humanity by His resurrection—precedes His ascent (after the third day). 
Of course, Eriugena, who is very careful in his Christological enunciations, notes that death (to be referred to in my text and without confining it to the mode of death, i.e., the cross) was "freely sought (sponte sua)": cf. Carm. 8.58.

Whether one takes the descent to Hades as the first phase of the resurrection or not. This is the rationale in Carm. 7.13-5, as well as in Carm. 6.23\&3.48-9: "he leapt up (prosilit) from Hell when three days had passed./After first crushing death he ascended (transivit) to Heaven". Furthermore, resurrection's ascent is also the necessary precondition for Christ's Ascension (little before the Pentecost).

Cf. John 3:13.

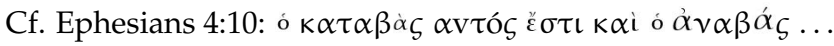

Cf. also Paul, Philippians 2:7-8.

Cf. Eph. 4:10 (my rendering).

Cf. also Matthew 12:40. In any case, in the paradoxical language of Heraclitus' B60DK: "The way up and the way down are one and the same"; cf. also (Vasilakis 2021a, p. 153), with reference to Dionysius, although I want to pursue this idea more in another article.

Eriugena had composed a poem praising Dionysius for the preface of his translation of the Corpus Dionysiacum: Carm. 21; cf. Herren-a, 152. Dionysius is also mentioned in 10.12-20 (with all the traditional false ascriptions, i.e., the identification of the saint who authored the Areopagitic Corpus with the convert of apostle Paul and with the bishop of Paris; see, though, Herren-a, 153 on Carm. 21.2).

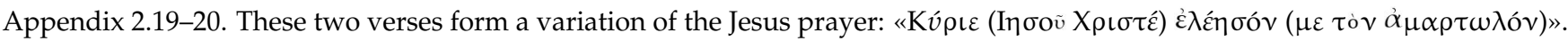
According to Herren-b, xlv-l, there is no doubt that this is a poem written by Eriugena. (Cf. also initial comment in Herren-a, 157.) There is also a similar gesture in Carm. 5.19-20, although there the first-person reference might be to the representative of the collective humanity, as well as what is at stake, death has a more straightforward ontological dimension than the ethical context of the previous reference to App. 2 (Still, as noted in n. 62, it would be a mistake to divorce these two dimensions, metaphysics and ethics, from one another). Since most of the poems were written for the Carolingian king Charles the Bald, there is usually a coda mentioning him (as it happens with great paintings that have as their theme, e.g., the Adoration of the Magi, while somewhere next to the main scene persons contemporary to the painter are pictured, too. Cf. also Herren-b, lxxiii). Thus, it is as if Charles would be praying for himself that Eriugena writes in Carm. 7.21-4: “O king, ..., /grant all prosperity to you Charles. Forgive in you servant (Indulge famulo) the taints of this fragile life,/ that he may see your kingdom with a heart that is pure (purus cernere)". (Cf. historical context in Herren-a, 143). However, a discordant note is stricken by the antisemitism of Carm. 9.62-73 (with Herren-a, 146-47).

Cf. 1 John 4:19.

More specifically, Christ is identified with the Tree of Life within Paradise in Periphyseon V.979B, 5413-4\&1015A, 7039-41 (Jeauneau).

Considering also John the Theologian's crucial implication in 1 John 4:20-21.

Cf. e.g., Carm. 9.52\&54-57: “As the lairs of Tartarus are emptied, bonds released/ . . /'Now I see', he [i.e., devil personified]

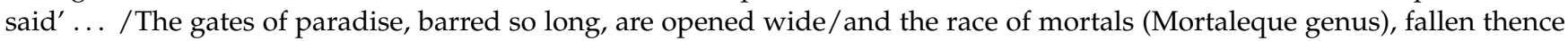
because of one man [sc. Adam]/Through one man's [sc. New Adam's/Christ's] death returns to its home beyond the stars". Cf. also Carm. 7.17-8.

One of the poem's words originally written (in its both occurrences) in Greek (misspelled but in the syntactically right declinations).

Cf. also Carm.9.1.

N.B. that Christ is called an "archiater" (leading doctor/physician) in Carm. 7.20.

This could be also a hint to the Eucharist. For a possible reference to the Eucharistic bread (panis), see Carm. 25.56-7\&61.

Vivere: note that some verses before (1l. 27\&25) $\mathrm{Z} \Omega \mathrm{H}$ (/Vita) is included in the divine names of Christ; cf. Dionysius, Divine Names, §6 with Rorem's n. 191 (in Pseudo-Dionysius 1987, p. 103) for the scriptural references.

Cf. also the Parable of the Wedding Feast in Matthew 22:1-14, esp.4/9/14.

Cf. ibid. and idem 25:32-3\&46 from the Parable of Judgement (/Sheeps and Goats).

Carm. 8.69\&71-9.

The word $\sigma \tilde{\omega} \mathrm{O} \zeta(<\sigma \omega \tau \eta \rho i \alpha=$ salvation) in Greek means "whole, integral" (not to be torn apart).

Eriugena extols Mary, the Mother of God, in Carm. 25.82-83 (on the occasion of a temple erected by Charles for Her devotion; cf. also 1.72).

Cf. Concilium universale Chalcedonense anno 451 in Acta conciliorum oecumenicorum, 2.1.1.35, 16-17 (Schwartz).

Concentrating on the (fourth) division of nature that is not created and does not create, i.e., on God as final cause. Another characteristic of this work is the frequent mention and interpretation of scriptural parables, which also justifies my condensed reference to them in the remainder of this paper.

The topic is, of course, relevant to Eriugena's earlier Treatise on Divine Predestination.

Cf infra, n. 109. 


\section{References}

Collette-Dučić, Bernard. 2014. Making friends: The Stoic conception of love and its Platonic background. In Ancient and Medieval Concepts of Friendship. Edited by Suzanne Stern-Gillet and Gary M. Gurtler. Albany: State University of New York Press, pp. 87-115.

Hard, Robin. 2004. The Routledge Handbook of Greek Mythology. Based on Herbert J. Rose's Handbook of Greek Mythology. London and New York: Routledge.

Hathaway, Ronald F. 1969. Hierarchy and the Definition of Order in the Letters of Pseudo-Dionysius: A Study in the Form and Meaning of the Pseudo-Dionysian Writings. The Hague: Martinus Nijhoff.

Heidl, György. 2020. Spousal Love beyond the Grave: The "Christian" Alcestis in Via Latina Hypogeum. In Masculum et Feminam Creavit eos (Gen. 1,27). Paradigmi del Maschile e Femminile nel Cristianesimo Antico. XLVII Incontro di Studiosi dell'Antichità Cristiana (Roma, 9-11 Maggio 2019). Edited by Massimiliano Ghilardi. Roma: Institutum Patristicum Augustinianum, Firenze: Nerbini International, pp. 69-75.

Iohannis Scotti Eriugenae. 1993. Carmina. Edited by Michael W. Herren. Dublin: Dublin Institute for Advanced Studies.

Iohannis Scotti Eriugenae. 2020. Carmina. Edited by Michael W. Herren and Adiuvante Andrew Dunning. Turnhout: Brepols Publishers, pp. vii-xc, 1-66, 167-84.

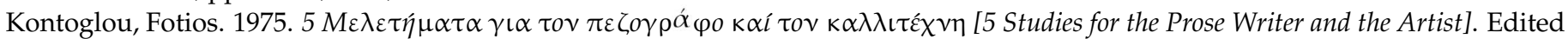
by Ioannis M. Chatzifotis. Athens: $\varepsilon \kappa \delta, ~ K \rho \iota \iota \iota \kappa \dot{v} \varphi v \hat{\lambda} \lambda \omega v$.

Layne, Danielle A. 2014. A Fatal or Providential Affair? Socrates and Alcibiades in Proclus' Commentary on the Alcibiades I. In Fate, Providence and Moral Responsibility in Ancient, Medieval and Early Modern Thought. Studies in Honour of Carlos Steel. Edited by Pieter d'Hoine and Gerd Van Riel. Leuven: Leuven University Press, pp. 267-90.

Loerke, Marc-Oliver. 2003. Höllenfahrt Christi und Anastasis-Ein Bildmotiv im Abendland und im christlichen Osten. InauguralDissertation zur Erlangung der Doktorwürde, Universität Regensburg, Regensburg, Germany.

Plato. 1997. Complete Works. Edited with Introduction and Notes by John M. Cooper. Associated by Douglas S. Hutchinson. Indianapolis and Cambridge: Hackett Publishing Company.

Proclus. 2011. Commentary on the First Alcibiades. Edited by Leendert G. Westerink. Translated by William O'Neill. Westbury: The Prometheus Trust. 
Pseudo-Dionysius. 1987. The Complete Works. Translated by Colm Luibheid. Foreword, Notes and Translation Collaboration by Paul Rorem. Preface by René Roques. Introductions by Jaroslav Pelikan, Jean Leclercq and Karlfried Froehlich. New York and Mahwah: Paulist Press.

Pseudo-Dionysius Areopagita. 2012. De Coelesti Hierarchia, De Ecclesiastica Hierarchia, De Mystica Theologia, Epistulae, 2nd ed. Edited by Günter Heil and Adolf M. Ritter. Berlin and Boston: De Gruyter, Corpus Dionysiacum. vol. II. First published 1991.

Proclus. 1985. Sur le Premier Alcibiade de Platon. Edited and Translated by Alain-Philippe Segonds. Paris: Les Belles Lettres, vol. 1.

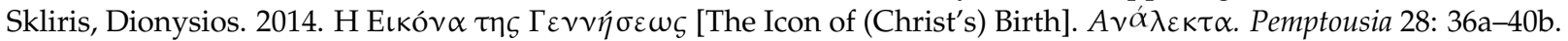

Sophrony, Archimandrite (Sakharov). 1999. Saint Silouan the Athonite. Translated by Rosemary Edmonds. Crestwood and New York: St Vladimir's Seminary Press.

Vasilakis, Dimitrios A. 2014. Neoplatonic Love: The Metaphysics of Eros in Plotinus, Proclus and the Pseudo-Dionysius. Ph.D. thesis, King's College London, London, UK.

Vasilakis, Dimitrios A. 2016. Maximus as a Philosophical Interpreter of Dionysius: The Case of Christ as Manic Lover. $\Theta \varepsilon o \lambda o \gamma i \alpha$ 87: 103-12.

Vasilakis, Dimitrios A. 2017. Dionysius versus Proclus on Undefiled Providence and its Byzantine Echoes in Nicholas of Methone. Studia Patristica XCVI/22: 407-18.

Vasilakis, Dimitrios A. 2019a. Neoplatonic Providence and Descent: A Test-Case from Proclus' Alcibiades Commentary. The International Journal of the Platonic Tradition 13: 153-71. [CrossRef]

Vasilakis, Dimitrios A. 2019b. On the Meaning of Hierarchy in Dionysius the Areopagite. In Platonism and Christian Thought in Late Antiquity. Edited by P. G. Pavlos, L. F. Janby, E. K. Emilsson and T. T. Tollefsen. London and New York: Routledge, pp. 181-200.

Vasilakis, Dimitrios A. 2021a. Eros in Neoplatonism and its Reception in Christian Philosophy: Exploring Love in Plotinus, Proclus and Dionysius the Areopagite, London, New York, Oxford, New Delhi and Sydney: Bloomsbury Academic.

Vasilakis, Dimitrios A. 2021b. A Neo-Platonic Dialogue on the Ethics of Love. In Love-Ancient Perspectives: The Metochi Seminar. Edited by K. Grødum, H. F. Hägg, J. Kaufman and T. T. Tollefsen. Oslo: Cappelen Damm Akademisk, pp. 81-99.

Vasilakis, Dimitrios A. forthcoming. The Hermeneutics of Dionysius' Platonic Writing Style. In Neoplatonists and Their Heirs: Christian, Jewish and Muslim. Edited by E. Anagnostou-Laoutides and Ken Parry. Leiden: Brill.

Wood, Jordan D. 2018. Creation is Incarnation: The Metaphysical Peculiarity of the Logoi in Maximus Confessor. Modern Theology 34: 82-102. [CrossRef] 